Kunduz Province 


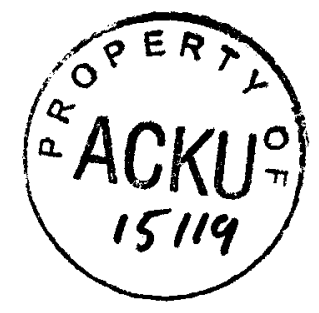

Kunduz Province 


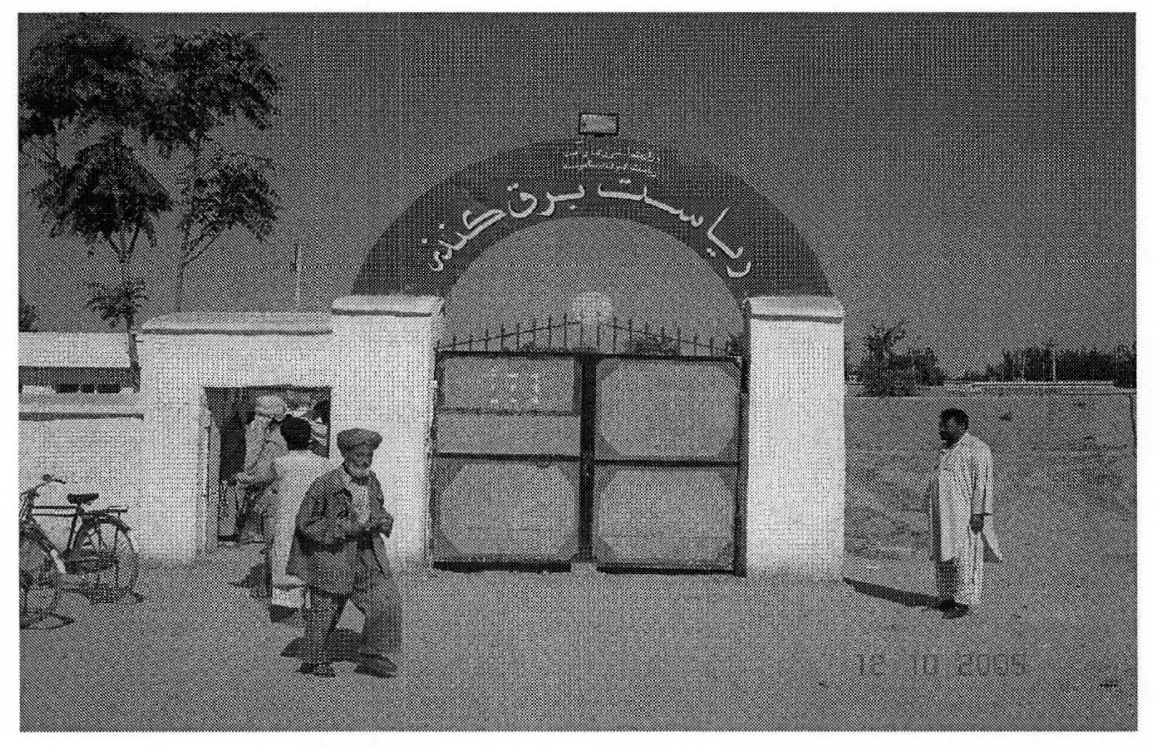

\section{Kundoz Province}

\section{Introduction of Kundoz Province:}

Kundoz province is one of the important province and its main way to north east and from geographical point it has border in north Tajikistan(Ammo River)from south Baghlan and Samangan from east Takhar province from west Balkh most of the people are busy in agriculture especially growing of rice, wheat ,Zegher (eating oil)and cotton and 30\% of the main cities like center of Kundoz ,Khanabad ,Imam Sahib ,Archi ,Chardara and Qala zal are Shopkeepers and 5\% people are working with government and more than $65 \%$ of people are formers.

After reaching to the Directorate of Kundoz DABM by 8:25Am we meet the following people:

1- Acting chief Director Alhag Mohammad Nawroz who is Finance manager Tel:079014600

2- Alhage Shah Mahmood Administrative Officer

Tel:079875423

3- Eng.Mohammad Anwar Deputy Technical of DABM

Tel:079421390

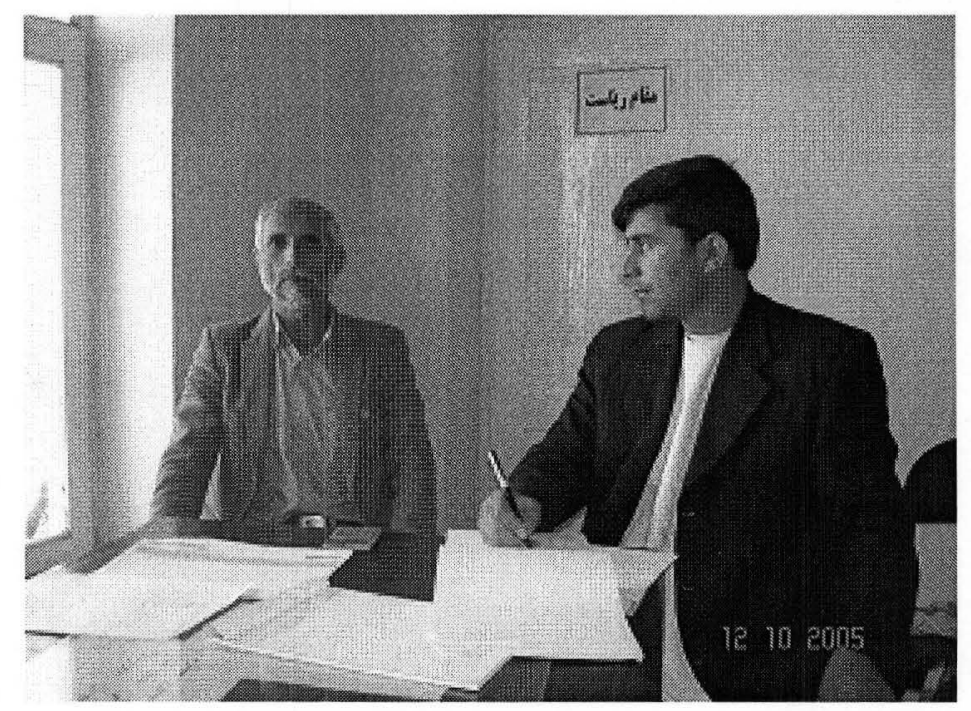




\section{Power Source:}

There is a mini hydro power in Khanabad district with the installed capacity of $4 \mathrm{x} 400 \mathrm{kw}$ that total $1,6 \mathrm{MW}$ that constructed by German and it was operational up to coming of Taliban and the power house has been destroyed during the Taliban war and above khanabad mini hydro power that there is an agriculture dam constructed by Country of India in 1977 the location of dam is in Pul-E-Chogha and it wan in plane to construct a hydro power with capacity of $9 \mathrm{MW}$, but now its working just for irrigation.

Current power of Kundoz Province is imported power form Tajikistan the length of Transmission line is $65 \mathrm{~km}$ one KWH of power is 2 cent and the conductor size is $120 / 28 \mathrm{~mm}^{\wedge} 2$ ACSR and cross section is steal.

Now the current system is designed for $110 \mathrm{kV}$ but as for as the Tajikistan Power Company was not ready for $110 \mathrm{kv}$ on that time but now $35 \mathrm{kV}$ is Transferring from Tajikistan. The current 110 transmission line has the capacity of 50MW also the contract between Tajikistan Afghanistan is for Five years (2002-2007) The reason for $35 \mathrm{kv}$ is that the Tajik people had problem in the their sub station and Kundoz DABM had shortage of insulator therefore Kundoz DABM connected their system with $35 \mathrm{kv}$ by this reason now they have $4.5 \%$ losses in the system this losses is from Tajikistan to Kundoz Sub station if in the current system $110 \mathrm{kv}$ in operation so the loss will be $0.6 \%$ (as its designed) also now one circuit breaker $35 \mathrm{kv}$ is in the border of Tajikistan and Afghanistan installed in case of transferring of $110 \mathrm{kv}$ as its designed the circuit breaker should be changed the new circuit breaker has to be $110 \mathrm{kv}$ type(VMT) also in our side our Insulators should changed from imported power seven layers in existing transmission line.

They have two revenue meter for controlling of reading number one in Tajikistan Sub station and number two in Kundoz Sub station the meter reading process is done each month by DABM Director of Kundoz then he is bringing the recording $\mathrm{KW} / \mathrm{h}$ and due to the reading they are paying the money to DA Afghanistan Bank then the bank transferring to Tajikistan Bank which is introduced.

\section{Demand in 2005(1384):}

The Demand in 2005 in Kundoz province is $20 \mathrm{MW}$ and in peak time the normal load is between $3-6 \mathrm{MW}$ and their current Sub Station has the capacity of 14MW.

Their monthly consumption is $3300 \mathrm{MWH} /$ month and 39600MWH/year.

The current consumption is $6 \mathrm{MW}$ divided as $1 \mathrm{MW}$ is for industrial \& residence, $5 \mathrm{MW}$ is for NGOs , City Lighting and the government areas.

\section{Existing Factories in Kundoz Province:}

Now they have six ice factory each factory consumption is $80 \mathrm{kw} / \mathrm{h}$ and the new factory of flour and the consumption is $350 \mathrm{kw} / \mathrm{h}$ and number of oil extractor (Zither) the consumption of each is $20 \mathrm{kw} / \mathrm{h}$. Lath machine and weld machine is available in the town.

\section{City Network of Kundoz:}

Kundoz Province has one main sub station in Kundoz city which has two transformer 110/35/6kv, 2x16MVA. 


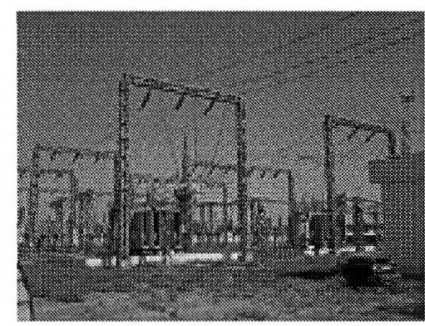

2x16MW -110/35kV Transformer
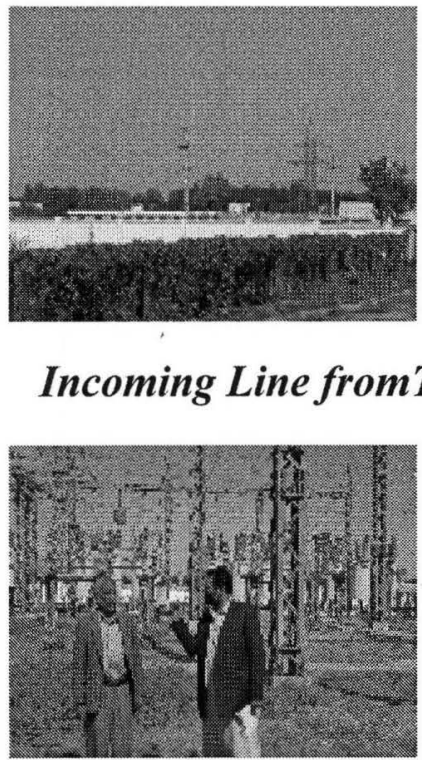

GPS point of Kundoz Sub station Is as follow:

$\mathrm{N}=36,44,777$

$\mathrm{E}=68,51,891$

$\mathrm{Ele}=1242 \mathrm{ft}$ with accuracy of $13.4 \mathrm{ft}$
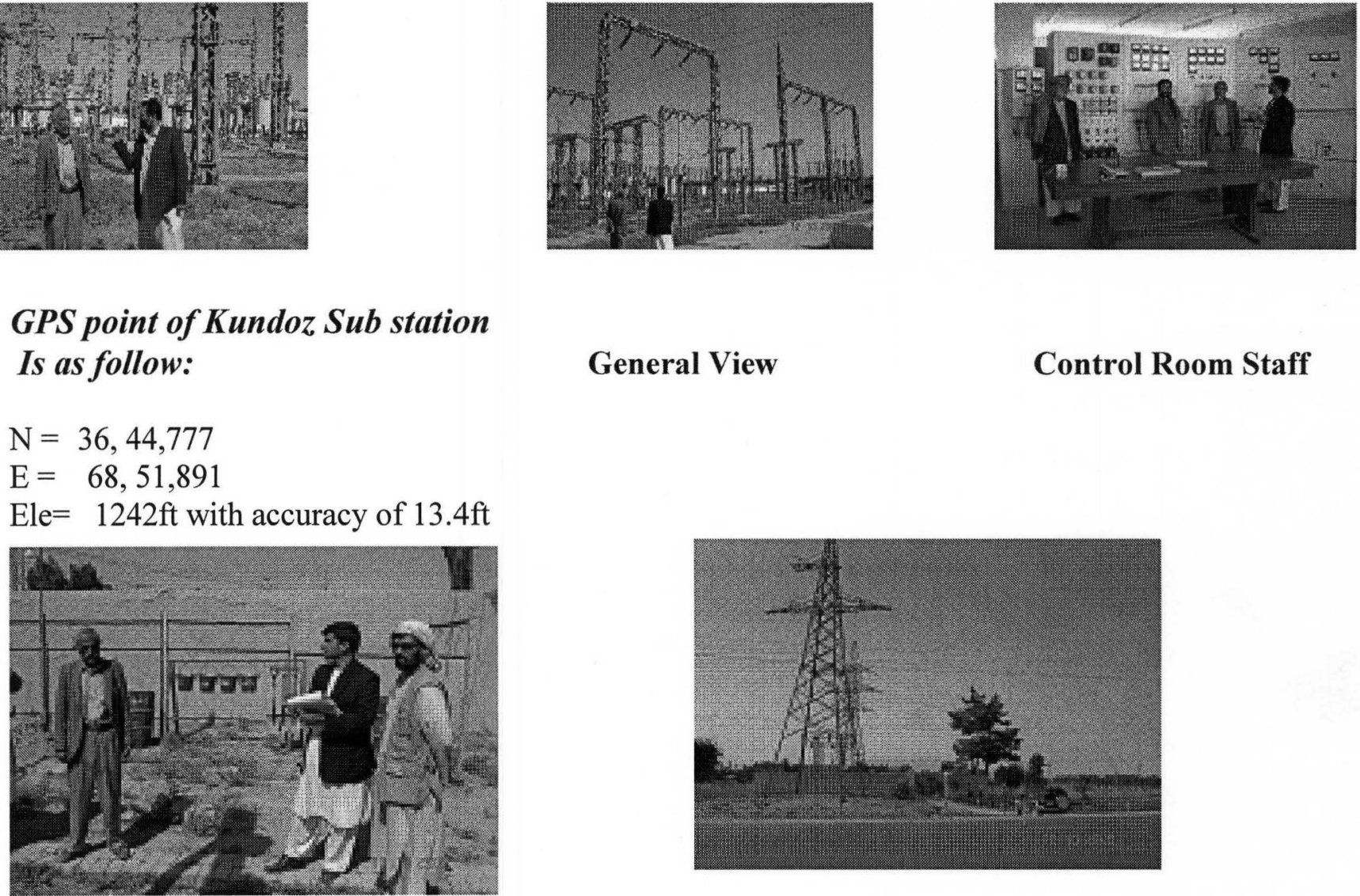

Joint of incoming line to Tran (35) $\mathrm{kV}$
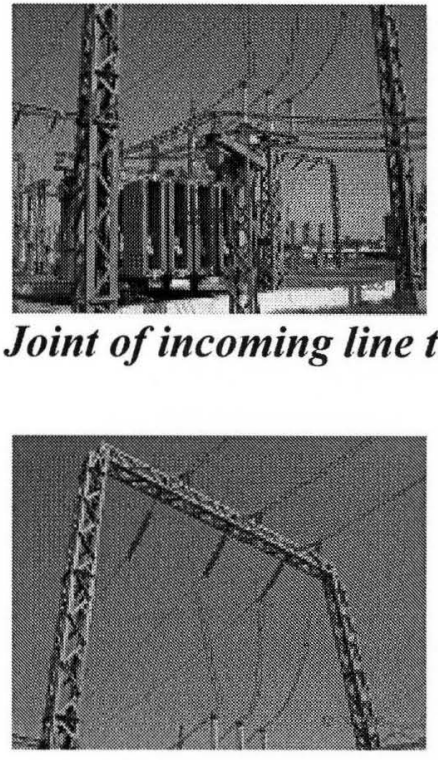

\section{Incoming Line from Tajik}

\section{Say Darak distribution Sub Station}

(Photo \# 1-2)

Tools and equipments needed are as follow:

1. Electrical gloves

2. Electrical Shows

3. Insulator Stick

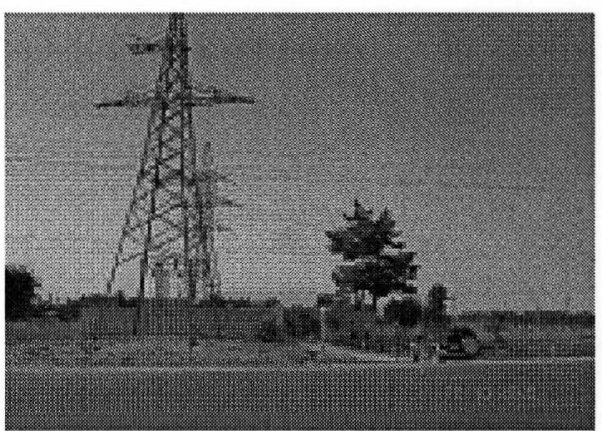


Kundoz mentioned sub station doesn't have any maintenance equipment.

Kundoz city has two Sub. Station:

1-Say Darak Sub Station has two transformers: $35 / 6 \mathrm{kv}(2 \times 1.6 \mathrm{MVA})$ in peak $800 \mathrm{kw} / \mathrm{h}$ with

GPS point as follow:

$\mathrm{N}=36,42,410$

$\mathrm{E}=61,58,89$

Ele $=1242 \mathrm{ft}$ with accuracy $13.4 \mathrm{ft}$

2-Imam Sahib Sub Station has one transformer 35/10kv (1x1MVA)

The existing network voltage is $6 \mathrm{KV}$ and it can be extended up to the radius of $8 \mathrm{~km}$ one thing the existing system is $6 \mathrm{kv}$ (old system) in case to change it to $20 \mathrm{kv}$ so the losses will be decreased and we will be to extend the distribution system in the radios of $30 \mathrm{~km}$ this idea is also written in the next five years plane the only district of Kundoz which right now has power is Chardara District

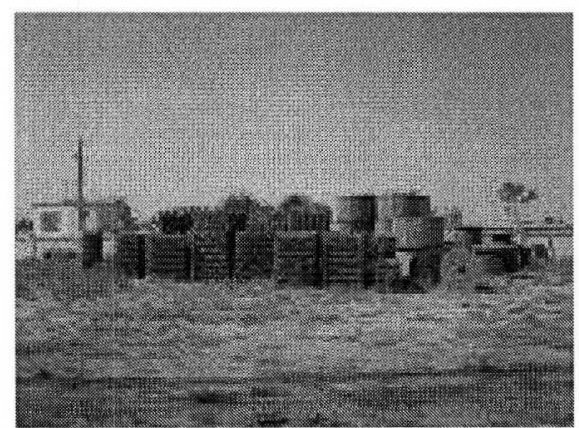

\section{Slitters:}

The new slitters which are stored in main sub station for the extend of the network.

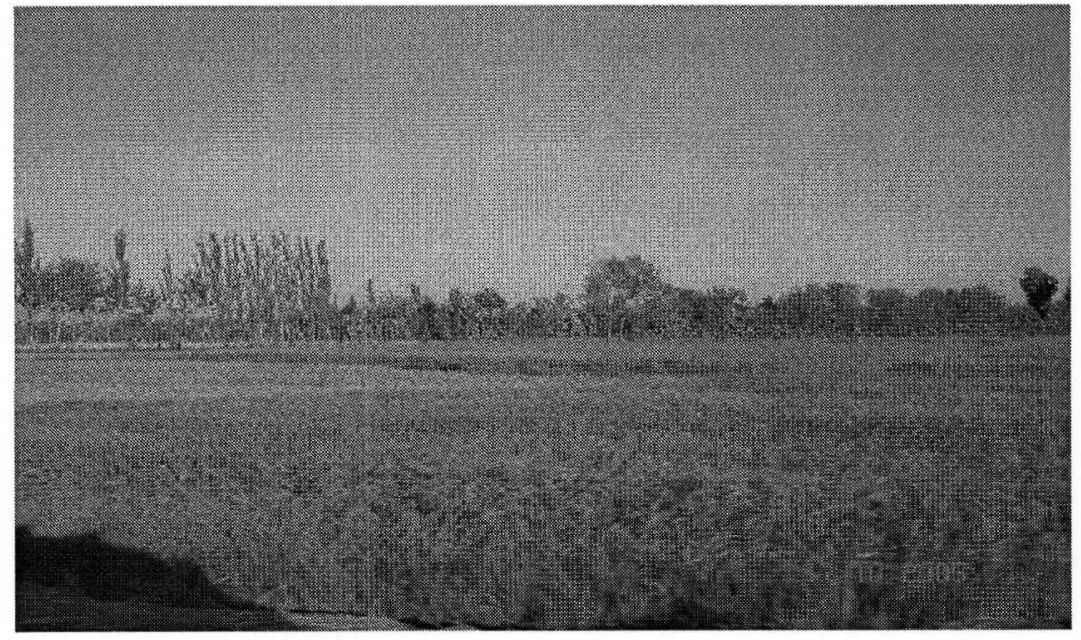

Agriculture land now has zegher (eating oil) 
Future demand in the next ten years:

It belongs to the development of provincial affairs for example this province is has the experience of cotton so if a textile factory can take about $3 \mathrm{MW}$.

\section{View of People:}

People are very interested to have power and always they co operate us for example they help DABM in purchasing of some small tools like Slitter of Junction and etc also the people are not interested to use power for cooking of food and heating because the price of gas and fuel are less cheaper than power also from DABM there is no restriction regarding use of power and one kwatt is 2.5 Afs for the residential area, 5 Afs for the Gov and industrial residential.

$\begin{array}{lcccc}\text { Diesel Fuel/Lit } & \text { Coal } / \mathbf{K g} & \text { Wood } / 7 \mathbf{k g} & \text { Gas } / \mathrm{Kg} & \text { Power } / \mathbf{K W H} \\ 32 \mathrm{Afs} & 3.5 \mathrm{Afs} & 50 \mathrm{Afs} & 35 \mathrm{Afs} & 2.5 \mathrm{Afs}\end{array}$

Kundoz Distribution System:

Existing problem of distribution system is network line which doesn't have reliable capability and efficiency and the thickness of lines are too small also last year they got some donation from World Bank including of tools $600 \mathrm{~m}$ Power line which is using for $400 \mathrm{v}(4 \times 240 \mathrm{~mm})$ and $(4 \times 95 \mathrm{~mm})$ but the quality was not poor please note that in the future should be in good quality.

\section{Meter reading Procedure:}

Now 10,000 reading devices have been purchased by DABM made of Turkey which are single phase and three phase and they also request for 8,000 more also stealing of power is common and in some places they installed reading devices is positioned in towers and transformers just to compare the total of the customers reading.

Those who have control in case if some thing different between their reading and the customers on that time DABM will distribute the total loss of power to all customers by this way DABM can take care of power stealing .

\section{Payment procedure:}

The reading procedure is after each two months by DABM and will be record in the Customers Note Book and payment is through the Bank.

In this system they have problem because people are not paying in the bank.

Our suggestion is to develop billing system for them to reduce this problem and have direct control on DABM incomes. 


\section{Number of Customers:}

Kundoz DABM has 14,500 customers in the existing system if it's extended from $6 \mathrm{kv}$ to $20 \mathrm{kv}$ the number of customers will be 25,000 customers and the average consumption of one family is approximately $0.5 \mathrm{kw} / \mathrm{h}$ and number of each family is ten people.

Annual Revenue -2004(1384):

For example last year 1383-2004 the revenue was as follow:

Revenue $============58,605,698 \mathrm{Afs}$

Expenses $============49,788,689 \mathrm{Afs}$

Profit $=============8,817,009$ Afs

\section{Number of DABM staff: 96 Person}

\section{Money Transferring Procedure to Kabul DABM:}

All income of Kundoz DAMB is going through to BANK in their own account if there is a requite for money from Kabul DABM they will transfer to their account for example 5,000,000 Afs has been delivered to Kabul DABM from the DABM Kundoz .

\section{Power usage:}

In regard usage of power there is no constraint from DABM to customers.

\section{Access of People with Electricity:}

$30 \%$ of the people has access on power and $70 \%$ doesn't have access the reason is that, the current system is $6 \mathrm{kv}$ and they cant to extend their network more than $8 \mathrm{~km}$ also three district doesn't have access to power the reason is that, the voltage is $6 \mathrm{kv}$ and they have suggested from MEW to give the order that they should use $35 \mathrm{kv}$ for transmission and $10 \mathrm{kv}$ for distribution and $\mathrm{MEW}$ is not agree because world bank has this program to make $220 \mathrm{kv}$ ring.

\section{Private Power Net work:}

There is no power net works (DG) also $90 \%$ of the people are using Tiger (small Generator) china Made One Tiger generator cost 60USD. 


\section{Takhar Province}

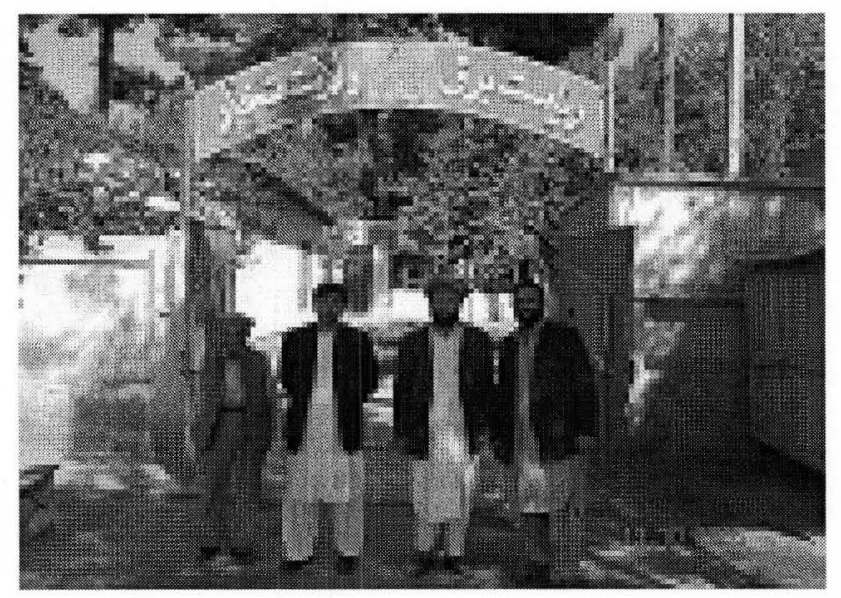

\section{Introduction of Taloqan center of (Takhar) Province:}

This province has 16district also from north is connecting to Tajikistan from south to Baghlan and Panjshir from east Badakhshan and from west to Kundoz Province also in the number of population is 150,000 people.

Most of the People in this province are busy with cultivation of wheat, rice and cotton and $5 \%$ of the people are working with government $95 \%$ of the people has their own business and $5 \%$ of the people are rich $20 \%$ are average $75 \%$ are poor.

Takhar people are very interested in small industry like flour mill oil extractor, ice factory etc one thing for the small industry they don't have power, so to use a DG is expensive to operate.

Regarding poppy cultivation last year they grow a lot but this year it's very limited.

\section{Source of Information:}

1. Director of DABM Takhar Ali Murad Imami

2. Eng.Abdul Manan Acting of Technical Officer

3. Mohammad Naeem Khan Accountant
Tel \# 070709511

Tel \# 070715195

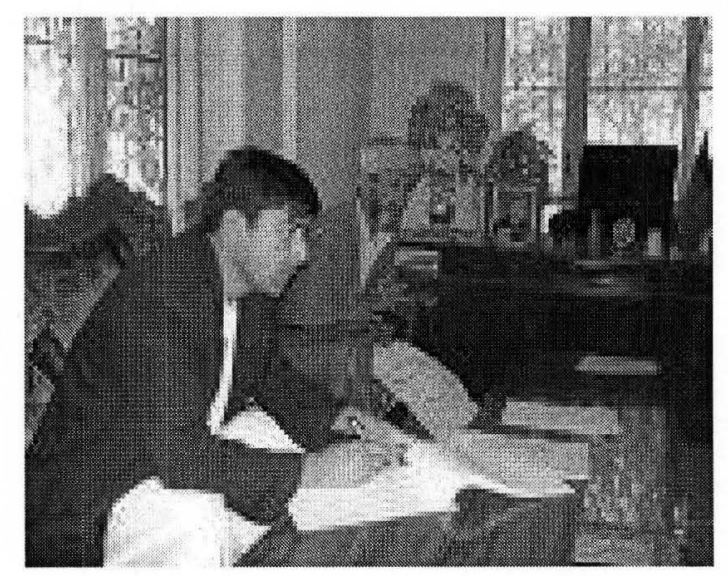




\section{Power Demand:}

Now for Takhar Province 10MW is the current anticipated.

In Takhar province 5,000 families are under the plan of municipality and each family has 10 people $80 \%$ people are interested to use electrical equipments

Taloqan city need 1,5MW power but now the current consumers are using $600 \mathrm{kw}$ in peak.

\section{Current power source:}

Some places has been survived for big hydro power which is registered by MEW with implementing of this plane it will resolve the problem in Taloqan province.

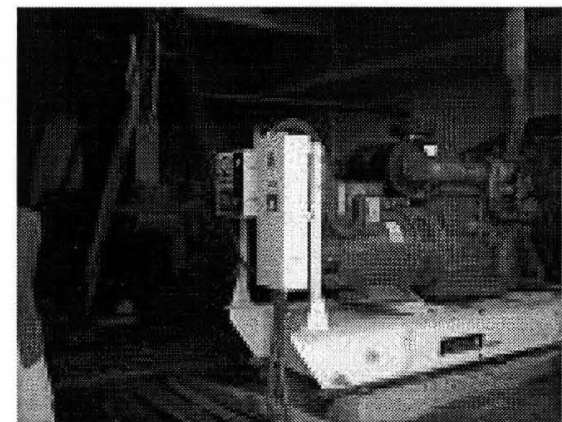

New DG 400KW (PARKIN)

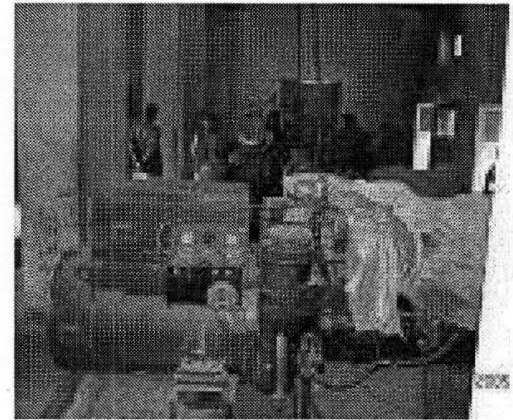

Old DG2X100KW

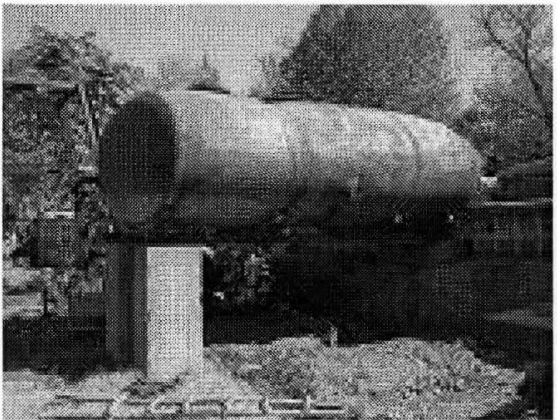

Fuel Reservoir

Now in Taloqan DABM they have Eight DG as follow:

1. $2 \mathrm{x} 64 \mathrm{kw}$ made of Russian 23 lit/h consumption which operational

2. $2 \times 100 \mathrm{kw}$ made of Russian not operational

3. $200 \mathrm{kw}$ made of Russian model k700 not operational

4. $400 \mathrm{kw}$ made of England model parkins operational consumption $108-113 / \mathrm{h}$

The GPS Point is as follow:

$\mathrm{N}=37,07,243$

$\mathrm{E}=70,35,124$

Elev $=4272 \mathrm{ft}$ with accuracy of $20,5 \mathrm{ft}$

5. $100 \mathrm{kw}$ made of Russian operation in Dasht Qala District is not used any more because of high price of Diesel.

6. $100 \mathrm{kw}$ Diesel Generator which locate in Khoje Ghar District is operational because of high coast of fuel is not operating.

$\begin{array}{lcccc}\text { Diesel Fuel/Lit } & \text { Coal } / \mathbf{K g} & \text { Wood } / 7 \mathrm{~kg} & \text { Gas } / \mathrm{Kg} & \text { Power } / \mathrm{KWH} \\ 35 \mathrm{Afs} & 5 \mathrm{Afs} & 40 \mathrm{Afs} & 45 \mathrm{Afs} & 25 \mathrm{~A}\end{array}$

\section{Existing Number of Customers:}

Now 600 customers are connected to the system the major of people demand power but DABM doesn't have enough power to distribute for the people.

\section{Annual income of $\mathrm{DABM}$ :}

As for as DABM don't have hydro generation the only source is DG and DABM doesn't have the budget for supplying of fuel. 
Before the fuel supply was supported by the shopkeepers of Taloqan city that each shopkeepers was supposed to pay 100Afs/Month this power was just for lighting of the city and for security this program was continued up to October-14 $4^{\text {th }}$ after while with lots of efforts of Director of DABM Taloqan he got the approval of 23,000Lit of Diesel Fuel for city lighting and now regards income they don't have income due to their experience even there ware not able to collect their invested money on fuel for DG.

\section{Number of DABM Staff:}

Actually the restructuring of Taloqan DABM is 50 people but now they have 20 people and their salary is not paid in the last four months.

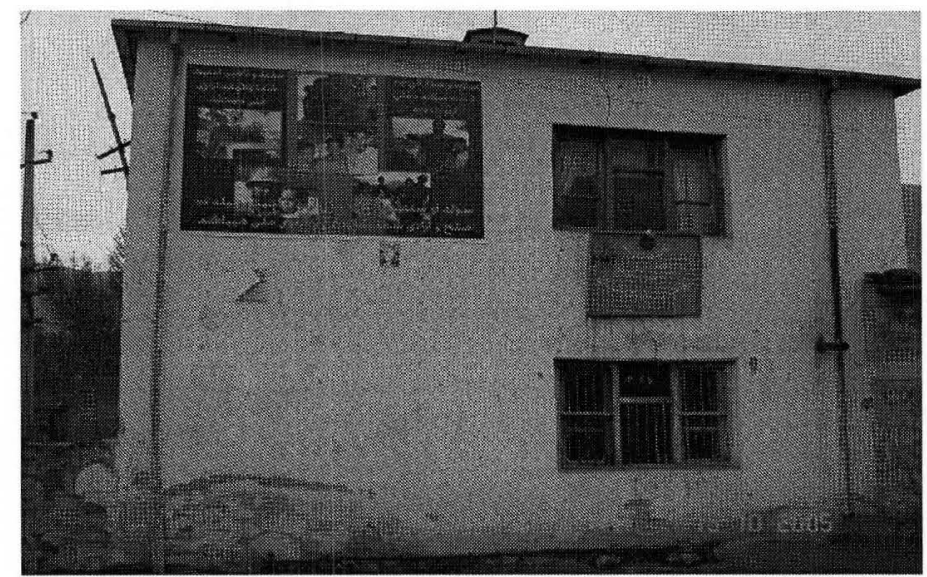

\section{Faizabad (Badakhshan Province)}

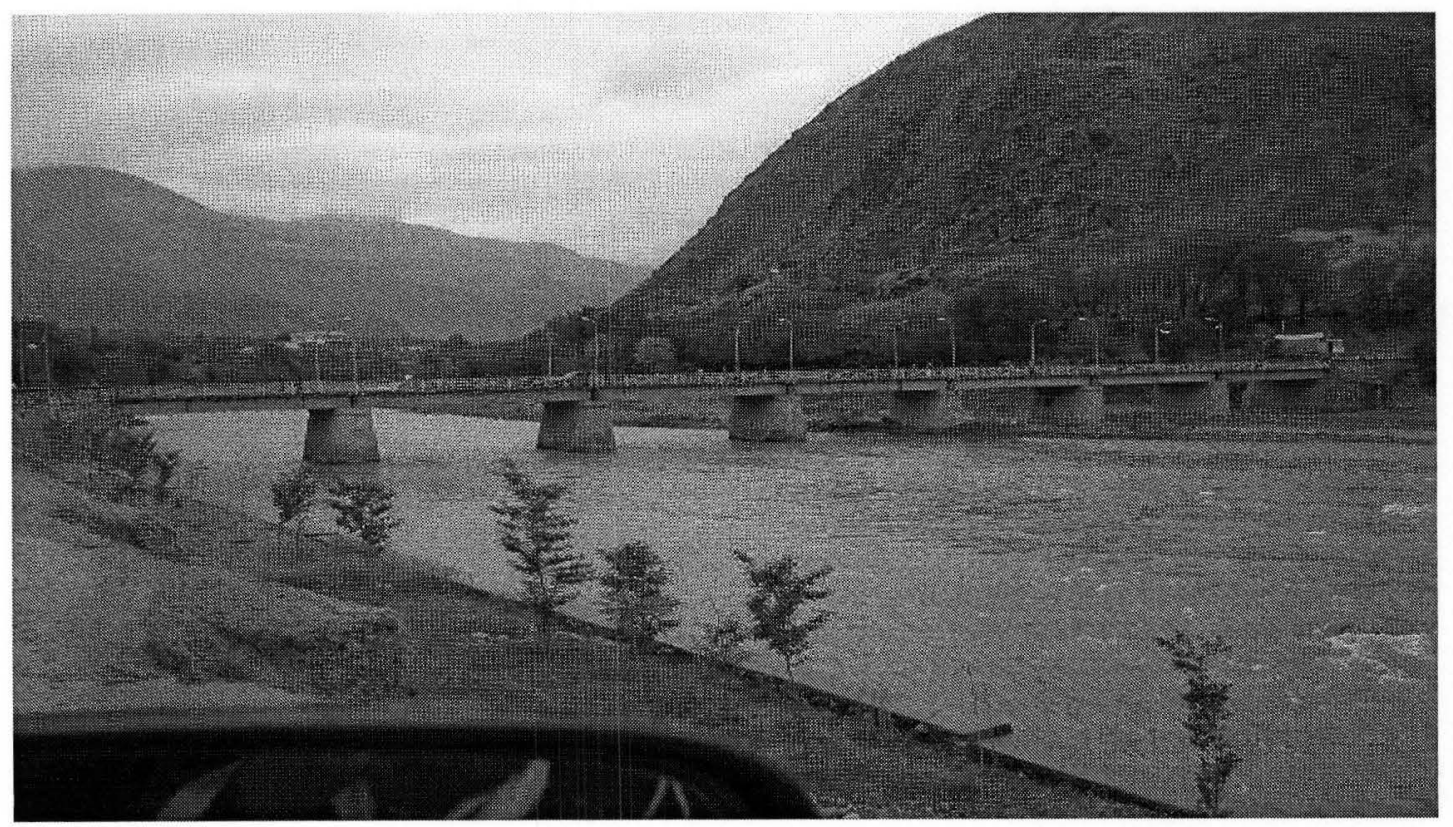

\section{Kokcha River of Badakhshan Province}




\section{Way to Faizabad Centre of Badakhshan Province(1-4)}

\section{Badakhshan Province}

\section{Introduction of Faizabad center of (Badakhshan) Province:}

Badakhshan province had border from north with Tajikistan south with Panjshir and noristan province and east with china and Kashmir west with Takhar the population of Badakhshan province is 1.5million and Faizabad city is 150,000 also has 28 district which more people are in Kishem and Baharak.

This province is a mountainous province that covers by hindokosh mountain most of these mountains have permanent snow by this reason small and large rivers are getting water for example Hamo River which has border between Afghanistan and Tajikistan,Panj River and Kokcha River by this reason most of the population are in Kishm and Darwas people don't have much agriculture land and just 30\% of people busy with agriculture most of income is from animal (Dairy and meat) also $60 \%$ of people have animal and fully busy.

Also in one year 7 months are winter and 5 months are summer .some people are busy in poppy cultivation and some are busy in business of Poppy but unfortunately some people are using it as a medicine and drug. By this purpose this province has major water in it and it has lots of possibility for Big Hydro and small Hydro Power project regarding big hydro which has are on Kokcha and panj river has been served by MEW and small micro hydro power like Shorabak Dam, Jorm, Chatta, Aurdar Micro Hydro which has been served by KOICA (Mr. Chan Jeong).

Less then $5 \%$ of People is working with government.

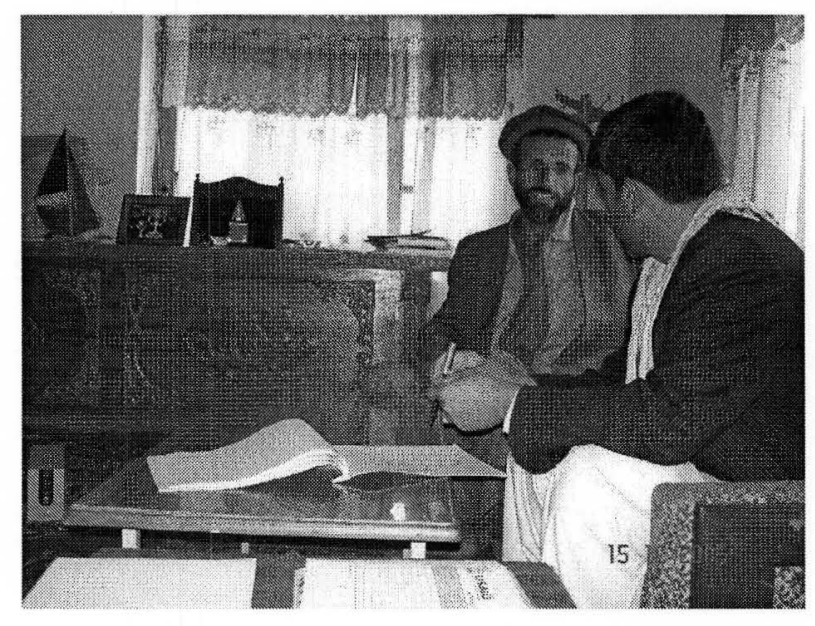

\section{Information Source:}

1. Said Mohammd Karim Production Director

2. Noor Mohammad Administrative Officer

3. Asamoddin Logistic Officer
Tel\# 079271147

Tel\# 079530461 


\section{Power Demand:}

Existing Power demand is $15 \mathrm{MW}$ and for the next five years2010 is about20MW.

\section{Number of DABM Staff: 39}
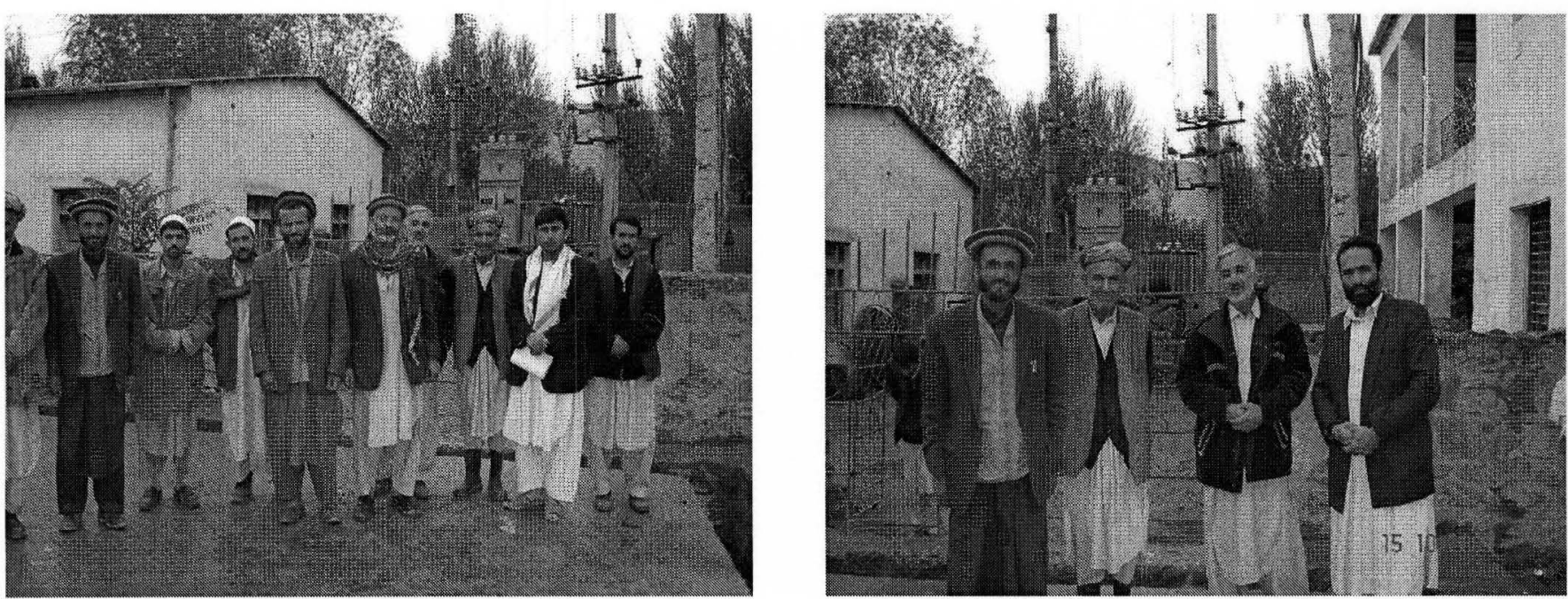

\section{Customers of DABM:}

Now 15000 families are living in Faizabad. 1800 family has connection in the city network and 250 family has accesses also $80 \%$ of the people are using small Generator Tiger.

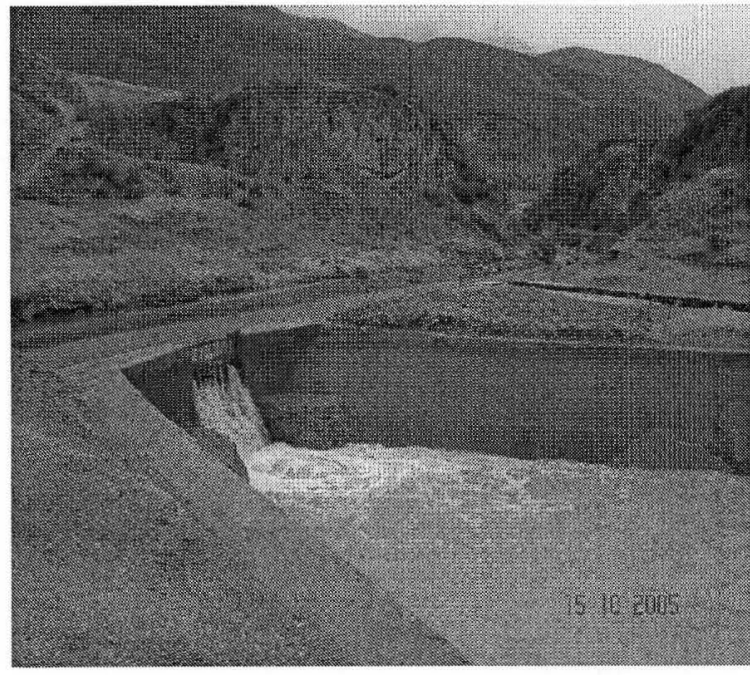

Forbey

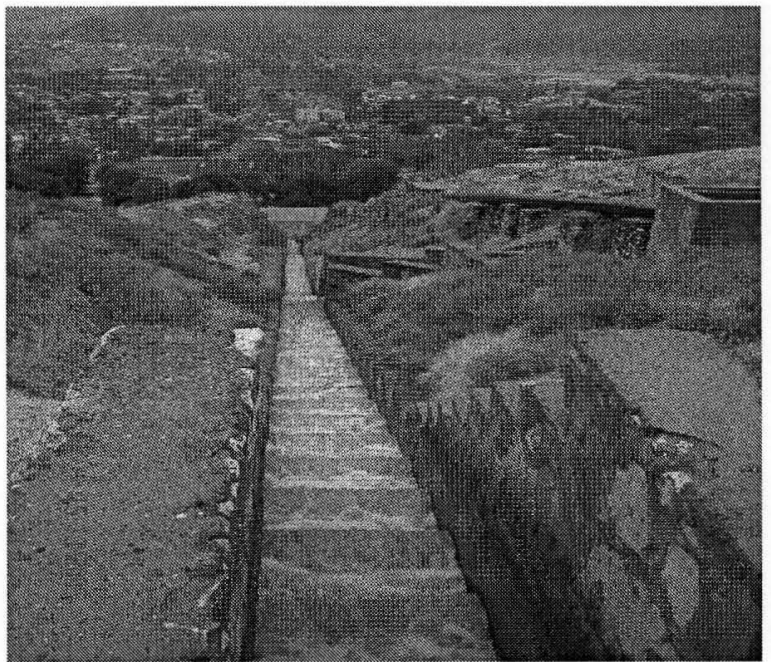

Spillway 


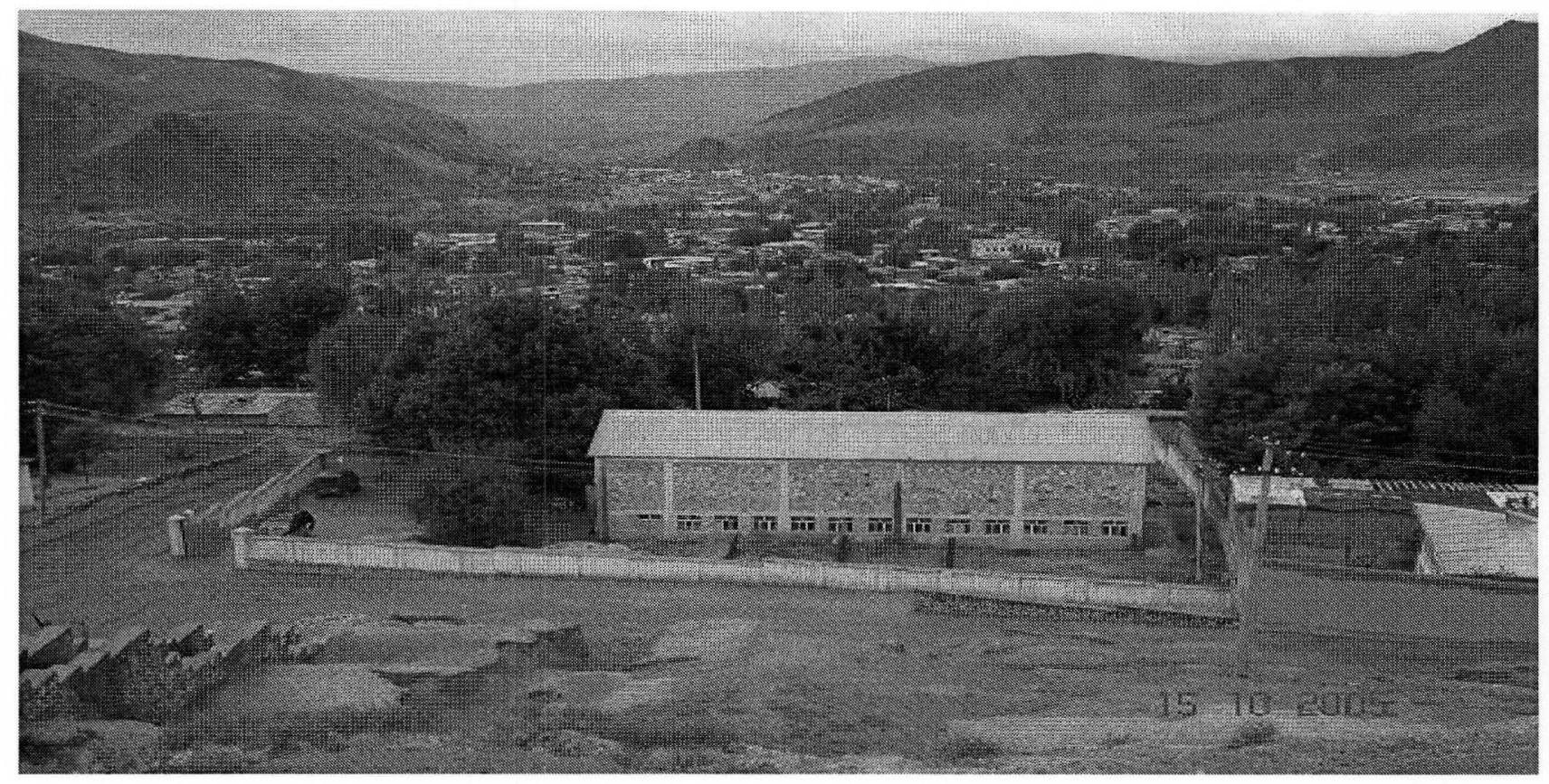

Power House Faizabad in Zegherchin Hill

\section{Existing Power Source:}

In 1983 three Turbines $3 * 85 \mathrm{KW}$ (PELTAN) type had been installed by Indian specialist in Television hile. Details are as follow:

Location $==============$ Zegher Chin Hile:

Head $=================50 \mathrm{~m}$

Water flow $==============520 \mathrm{lit} / \mathrm{s}$

Main Pen stock Dia======== $=500 \mathrm{~mm}$

Few years ago before drought which they had maximum water two units $(2 * 85) \mathrm{kw}$ were Generating and one unit was spare.

The PELTAN type turbines are already completed its actual live and no one took care of maintenance and rehabilitation is not done also one reason shortage of water.

Then during Mr.Rabanee Presidency according request of DABM Faizabad they changed two old unit and installed two new one with the installed capacity of $250 \mathrm{kw}$ by Tajikistan Specialist after the erection the result was not meet the requirement which was expected the reason if not meeting the requirement is each unit needs above 1 cubic meter water as for as it not meeting the requirement is standby and the existing generation is from Indian Turbine $85 \mathrm{Kw}$ which produce maximum $45 \mathrm{KW}$ and its just for the use of Hospital,Gov and some residential . 


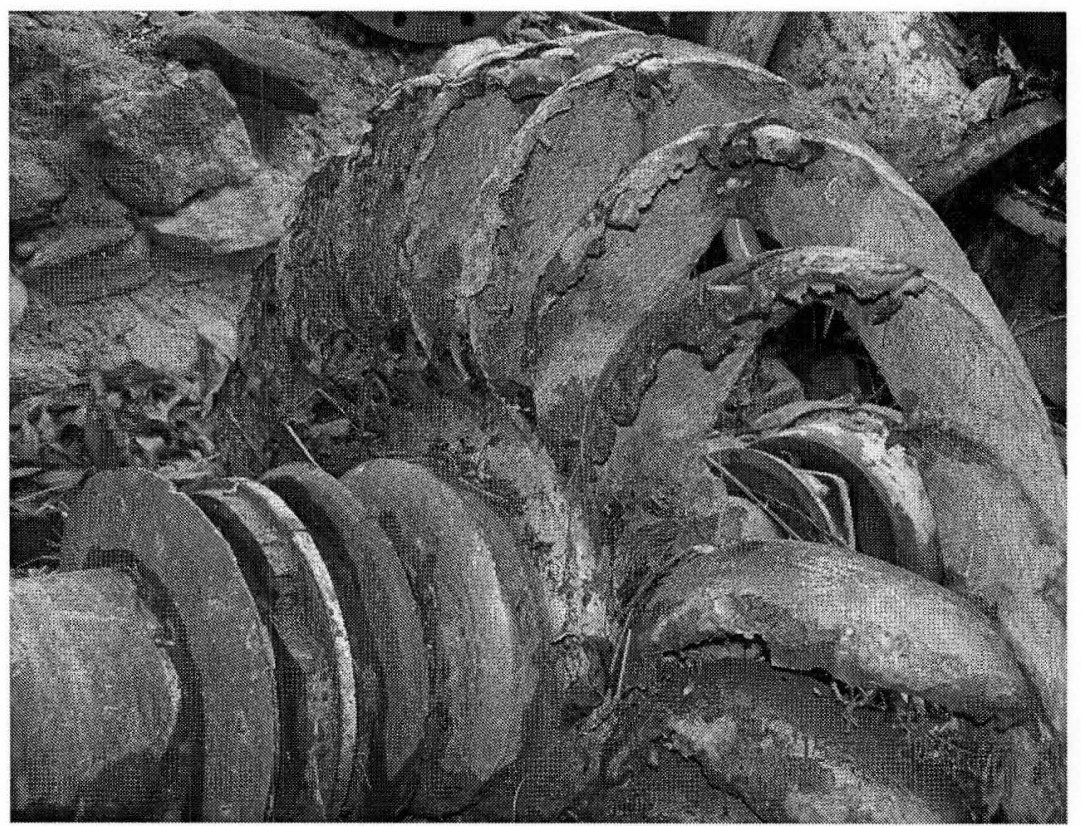

Old Runner of mini hydro

\section{The GPS point of the mini hydro power plant is as follow:}

$\mathrm{N}=37,07,167$

$\mathrm{E}=70,34,538$

Ele $=4011 \mathrm{ft}$ with accuracy of $24,4 \mathrm{ft}$

\section{Amazing Point:}

In the existing generation $45 \mathrm{kw}$ it's not permanent.

1. three months of spring flood season

2. three months of fall drought season

3. three months of winter the surface of water is taking ice

4. Three months of summer is working condition but and needs repair.

Other sources of Power (DGs) in Faizabad DABM are as follow:

1. One DG $(480) \mathrm{KW} / \mathrm{H}$

The DG 480KW it's not operating because the price of diesel if so high and stealing of power is in the network.

2. Two DG $160 \mathrm{KW}$ needs diesel pump to be changed not operational

3. one DG $80 \mathrm{KW}$ is operational

4. One DG $160 \mathrm{KW}$ in district four

5. One DG $100 \mathrm{KW}$ in district five

DG 160 \& 100KW which belong to DABM and has Russian Engine and the fuel cost was too high the People suggested from DABM to that we will change the Generator Engine to reduce the fuel consumption and the income will be collected by the people and some percentage will be given to the DABM. 


$\begin{array}{lcccc}\text { Diesel Fuel/Lit } & \text { Coal } / \mathbf{K g} & \text { Wood } / 7 \mathbf{k g} & \text { Gas } / \text { Kg } & \text { Power/KWH } \\ 48 \mathrm{Afs} & 10 \mathrm{Afs} & 65 \mathrm{Afs} & 45 \mathrm{Afs} & 30 \mathrm{Afs}\end{array}$

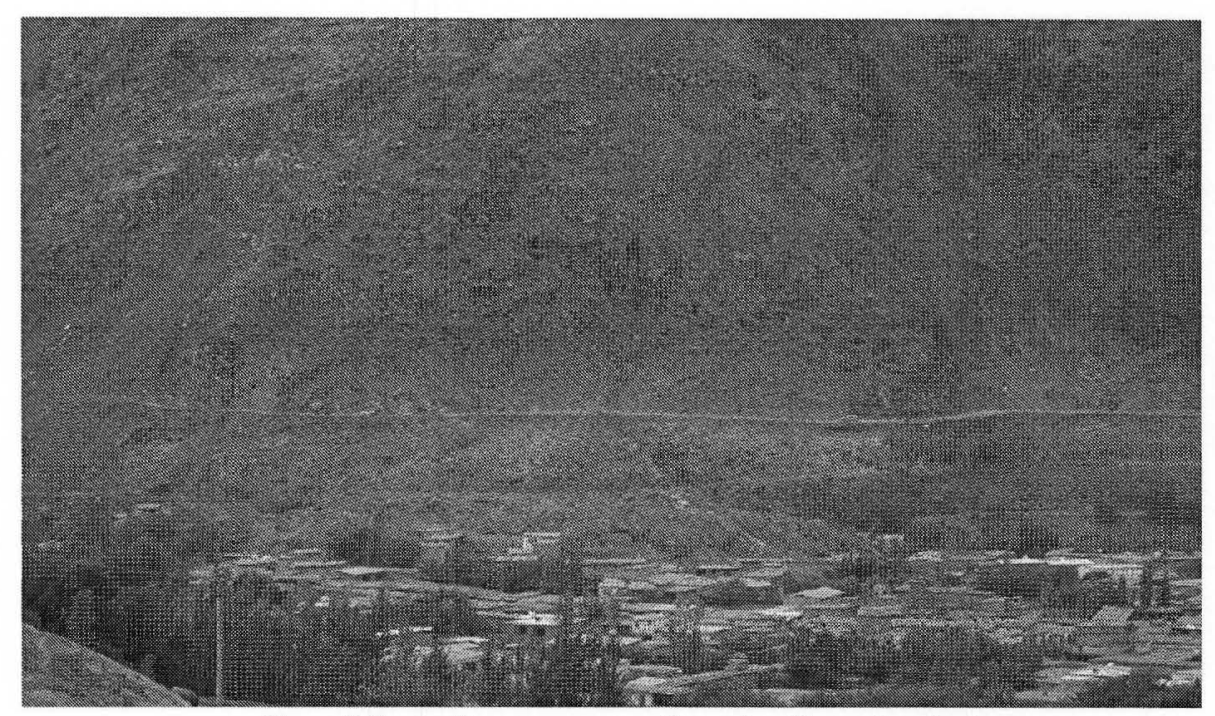

One View from part of main Road of city

\section{City Net Work:}

The existing network has $80 \%$ losses because they don't distribution transformer they have just two transformers step up in hydro power plant $400 \mathrm{~V} / 10 \mathrm{kv}$ and step down transformer $10 \mathrm{Kv} / 400 \mathrm{Vin}$ city sub station also per kilo watt power is 30Afs even this cost is not a good income and from one year they don't received their salary.

\section{Annual Expenses:}

The annul expenses in $2004=====6,633,635$

Annual Income:

The annual income in $2004======2,525,981$

The monthly expenses if they use fuel monthly consumption of diesel fuel are 190,000lit.

\section{Conclusion}

Thanks,

Eng.Mohammad Arif Arghoshi 


\section{Sky News Italia s.r.l.}

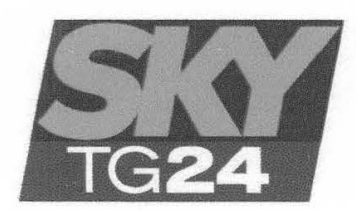

Via Salaria, 1021 - 00138 Roma

Tel. +3906882281.9175

Fax +390688663358

To whom it may concern

I covered the political elections in Afghanistan in September 2005 on behalf of my TV news channel - SKY TG24, Italy's only all-news channel that airs around 39 bulletins daily plus several special programmes, and is part of SKY ITALIA.

During my stay in Afghanistan I had the pleasure of working with Mr Ahmad Omar Ahmadi, as my translator and producer. I was extremely impressed by his skill, kindness and consummate professionalism and would be honoured to work with him. Both I and my Editor in Chief highly recommend Mr Ahmadi. He is a trustworthy and honourable gentleman and I look forward to working with him in the not too distant future.

Sincerely,

Alessandra Cardone 